\title{
Population and feeding structure of Steindachnerina notonota Miranda-Ribeiro, 1937 (Actinopterygii, Characiformes, Curimatidae) in Taperoá II dam, semi-arid region of Paraíba, Brazil
}

\author{
Estrutura populacional e alimentar de Steindachnerina notonota Miranda Ribeiro, 1937 \\ (Actinopterygii, Characiformes, Curimatidae) no Açude Taperoá II, \\ na região do semi-árido da Paraíba, Brasil
}

Ana Karla Araujo Montenegro ${ }^{1}$, Jane Enisa Ribeiro Torelli ${ }^{3}$,

Maria Cristina Crispim ${ }^{3}$ and Ana Maria Alves Medeiros ${ }^{2}$

${ }^{1,2}$ Programa de Pós-Graduação em Ciências Biológicas, Laboratório de Ecologia Aquática,

Departamento de Sistemática e Ecologia, Centro de Ciências Exatas e da Natureza,

Universidade Federal da Paraíba - UFPB, Cidade Universitária, Campus I, CEP 58059-900, João Pessoa, PB, Brazil

e-mail: biokarla_21@hotmail.com; ana.maria.bio@gmail.com

${ }^{3}$ Laboratório de Ecologia Aquática, Departamento de Sistêmica e Ecologia,

Centro de Ciências Exatas e da Natureza, Universidade Federal da Paraíba - UFPB,

Cidade Universitária, Campus I, CEP 58059-900, João Pessoa, PB, Brazil

e-mail: janetorelli@yahoo.com.br; ccrispim@hotmail.com

e-mail: ana.maria.bio@gmail.com

\begin{abstract}
Aim: The present study investigated population structure, weight-length relationships, sex ratio and associations between feeding activity and reproductive period, diet and alimentary regime of Steindachnerina notonota at Taperoá II dam, semi-arid region of Paraíba State. Methods: The region has the lowest pluviometric rates of Brazil. Fishes were collected during six sampling periods (October and December/2005, and March, June, August and October of 2006) encompassing two dry periods, and one rainy period. Cast, seine and gill nets were used to collect the individuals. Results: Throughout the study period 120 individuals were collected, with total length ranging between 2.2 and $10.7 \mathrm{~cm}$ and weight between 0.31 and $43.1 \mathrm{~g}$. A recruitment period, identified due to a higher abundance of small individuals in the population, was observed in the beginning of the rainy period of 2006, lasting until the beginning of the dry season. S. notonota showed a negative allometric growth type, i.e., individuals 'elongate' during their development. A significantly higher proportion of females were observed throughout the study period. The relationship between feeding and reproductive activities were not significant, given that individuals showed high feeding rates regardless of the intensity of their reproductive activities. Although the diet of $S$. notonota comprised several items such as plant debris, eggs, organic matter, phytoplankton, zooplankton, Nematoda, Ostracada, Conchostraca, among others, the most important feeding item was detritus, suggesting a predominant detritivirous feeding habit. Conclusions: Biological aspects of $S$. notonota observed in the present study suggest that this species has potential to attain great population sizes, as consequence of both diet and feeding dynamics, as well as its reproductive characteristics and growth type.
\end{abstract}

Keywords: diet, Curimatidae, population structure, semi-arid, fishes.

Resumo: Objetivo: $\mathrm{O}$ presente estudo investigou a estrutura da população, a relação peso-comprimento, a razáo sexual, as associaçóes entre atividade alimentar e período de reproduçẫo, dieta e regime alimentar de Steindachnerina notonota, no açude Taperoá II, semi-árido paraibano. Métodos: A regiâo tem os menores índices pluviométricos do Brasil. Os peixes foram coletados em seis amostragens (Outubro e Dezembro de 2005, e Março, Junho, Agosto e Outubro de 2006), compreendendo 2 períodos de estiagem e 1 chuvoso. Para a captura dos exemplares, utilizou-se tarrafa, redes de espera e de arrasto. Resultados: Ao longo do estudo capturou-se um total de 120 indivíduos, que mediram entre 2,2 e 10,7 cm de comprimento total e pesaram de 0,31 a 43,1 g. Evidenciou-se intenso recrutamento durante todo o período estudado, demonstrado pela maior abundância de indivíduos em estádios gonadais "em maturação" (2) e "maduros (3)". S. notonota apresentou um crescimento do tipo alométrico negativo (quando os indivíduos 
se tornam mais "alongados" durante o seu desenvolvimento), com uma proporção sexual significativamente maior de fêmeas ao longo do período estudado. Observou-se que a relação entre a atividade alimentar e a atividade reprodutiva náo foi significativa, tendo em vista que os indivíduos apresentaram alta atividade alimentar independente da intensidade da atividade reprodutiva. Embora a dieta alimentar de $S$. notonota tenha sido composta por diversos itens, a exemplo de restos vegetais, ovos, matéria orgânica, fitoplâncton, zooplâncton, Nematoda, Ostracoda, Conchostraca, dentre outros, o item de maior importância alimentar foi detritos, indicando um regime alimentar predominantemente detritívoro. Conclusóes: Os aspectos da biologia de $S$. notonota observados no presente estudo, remetem a uma espécie com potencial para atingir grandes tamanhos populacionais, tanto pela sua dieta e dinâmica alimentar, quanto pelas suas características reprodutivas, e tipo de crescimento.

Palavras-chave: dieta, Curimatidae, estrutura populacional, semi-árido, peixes.

\section{Introduction}

Given their great diversity, abundance and mobility, fishes play a key role in food chains of aquatic ecosystems (Soares et al., 1986). However, recent estimations indicate that this group has lost approximately $20 \%$ of its global diversity, mainly due to habitat degradation, overfishing and introduction of exotic species (Fernando, 1991; Latini, 2001).

Specific knowledge on the biology and population dynamics is, therefore, necessary to understand and preserve natural fish stocks by means of sustainable utilization. Furthermore, studying these aspects provides important information on possible environmental disturbances, given that fishes ultimately show specific responses to these variations. Within Brazilian northeastern microregions, in the semi-arid the water levels vary from total absence (dry periods) to great discharges (rainy season) in most aquatic environments.

As a consequence, semi-arid communities have developed adaptations of morphological, physiological and behavioral nature to cope with these harsh conditions, thus perpetuating individual survival and, ultimately, the maintenance of local populations throughout time (Cowx et al., 1984).

The length-frequency distribution of a species provides essential support to estimate fish age and growth, particularly for juveniles (Benedito-Cecílio and Agostinho, 1997). These distribution patterns and their possible alterations through time and space provide knowledge on the population dynamics and may also identify problems such as low recruitment, slow growth and excessive annual mortality. Quantitative information regarding weight-length relationships, condition factors, sexual proportion, growth, recruitment and mortality of a particular fish species is an important tool for studies aiming to provide information for fisheries and essential for management and environmental conservation (Vazzoler, 1996; Lizama and Agostinho, 2003; Vicentini and Araujo, 2003), aside from being good indicators of feeding and reproductive activities (Teixeira and Gurgel, 2005).

Steindachnerina notonota (Miranda-Ribeiro, 1937), regionally known as "saguiru", belongs to the Curimatidae family. The family comprises small individuals that feed on bottom debris and lack iliophag teeth, feeding on bottom debris (Britski, 1972). This species is endemic to the ecoregion of Maranhão-Piauí and to the Mid-Northeastern region of Brazil, but its phylogenetic relationships are still poorly defined (Rosa et al., 2005). Individuals of this species also migrate during reproductive periods.

Considering the lack of detailed investigations on the population structure and feeding habits of Brazilian semi-arid fishes of the Caatinga, the aim of this work was to determine the population structure based on length classes, weight-length relationships, sexual ratio, associations between feeding activity and reproduction period, and feeding habits of S. notonota in Taperoá II Dam, Paraiban semi-arid region.

\section{Material and Methods}

\subsection{Study area}

The semi-arid in Northeastern micro-regions is known for its deficit of water resources caused by low precipitation and high evaporation rates which, as a consequence, accelerate the eutrophication processes of aquatic systems. Also, periodically and during a relatively short period, these aquatic systems may shift from dry to overflow. 
In the semi-arid region of Paraíba state, Northeastem Brazil, hydrological cycles have a major influence on population structure of fish assemblages, and although a recent increase in studies accomplished in this area is noticeable (Cardoso et al., 2004; Chaves et al., 2009, Montenegro et al., 2006; 2010), it remains relatively understudied.

Taperoá II Dam is a permanent section of the Taperoá River Basin, located in Taperoá municipality, central Paraíba State (Figure 1). It has a maximum volume capacity of $15,148,900 \mathrm{~m}^{3}$ of water and has a surface area of $4.6 \mathrm{~km}^{2}$ and a maximum depth of $5 \mathrm{~m}$.

The study area is under two well-defined seasons, namely, the rainy season, which typically lasts between three and four months, and the dry season, which prevails during most of the year. The climate is semi-arid, hot and dry, and the rainy season usually takes place during the Summer/Autumn
(Köppen, 1900) in the Southern hemisphere, which corresponds usually to as few months in the first semester. With approximately $300 \mathrm{~mm}$ /year, this area has the lowest precipitation rates in Brazil (Pimenta-Filho et al., 2004).

\subsection{Sampling}

Fishes were collected in October and December of 2005 (dry season), March and June of 2006 (rainy season), and August and October of 2006 (dry season), at sites highlighted in red (Figure 1). Precipitation rates and dam volume during the study period are shown in Figure 2.

Fishes were collected with the following fishing gears: 2 cast and 2 seine nets (mesh size of $15 \mathrm{~mm}$ between adjacent knots, nylon bags with $0.2 \mathrm{~mm}$ of net aperture); and 5 gill nets (meshes of 15, 20, 25, 35 and $40 \mathrm{~mm}$ between adjacent knots), during six sampling periods, along 24 hours, checked every 4 hours. These different

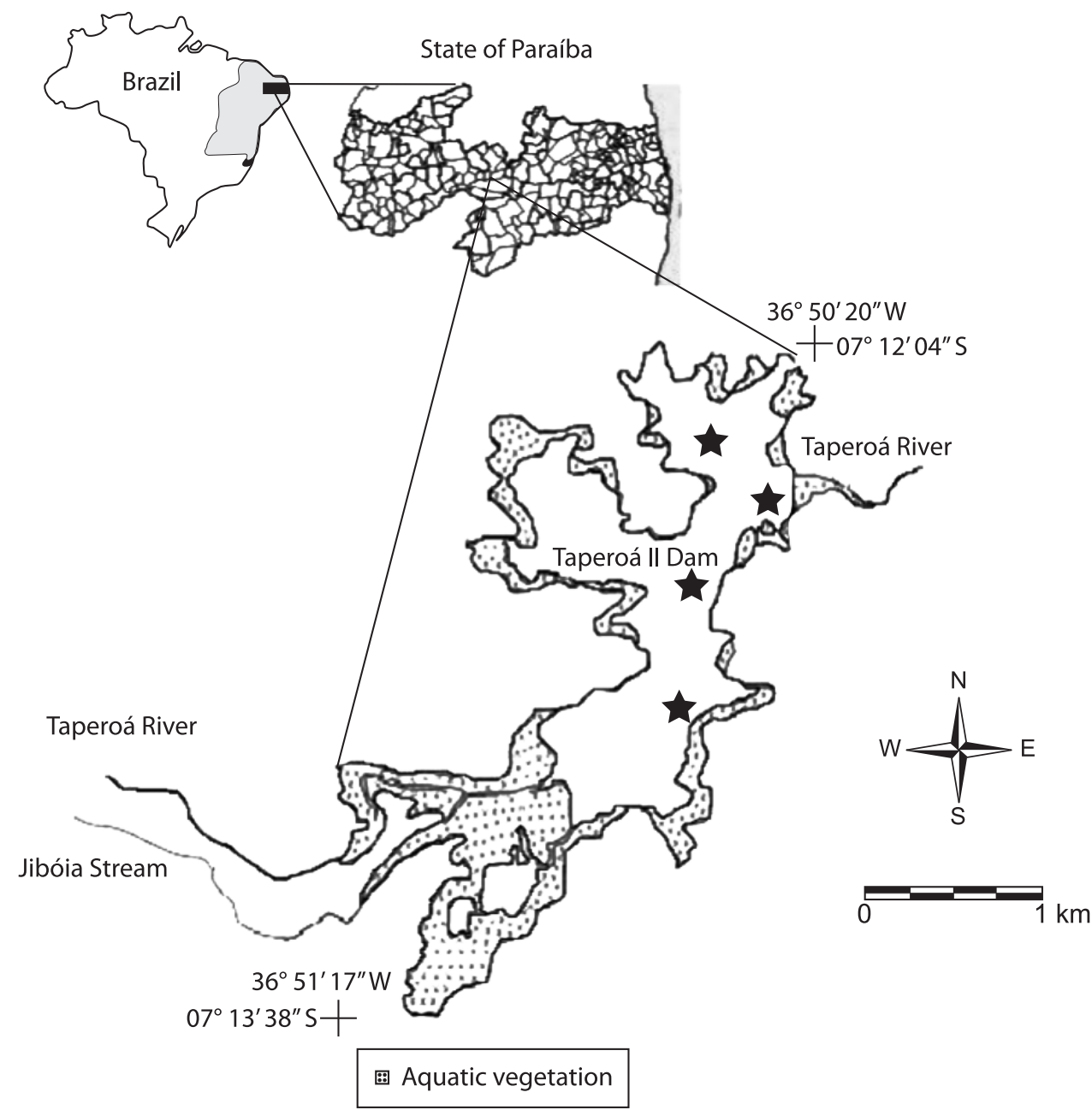

Figure 1. Location and map of the Taperoá II dam, Taperoá city, Paraíba State, Brazil. 


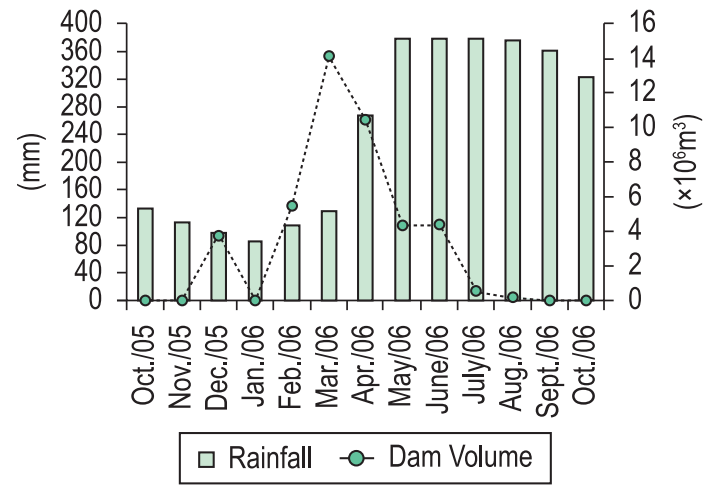

Figure 2. Pluviometric indexes (bars) in the Taperoá region and volume (lines) in the Taperoá II dam, reg istered during the study period (Source: AESA, 2007).

types of gear were used to enhance fish capture from various size classes and microhabitats, both during the day and night periods.

Specimens were fixed in a $10 \%$ buffered formalin solution in field, and, later, taken to the laboratory of Aquatic Ecology/DSE/UFPB, where taxonomic identification was confirmed based in Vari (1991) and with the aid of a taxonomic specialist. Voucher specimens were deposited in the Icthyological collection of UFPB (under $n^{\circ}$ 6180).

\subsection{Population structure}

To determine population size structure, specimens were measured (standard length), being classified as males, females or immature by the observation of the maturation stage of gonads (Vazzoler, 1996). The $t$-test was applied to evaluate the differences in size between male and female through the studied period, and by isolated seasons.

The length-weight relationship was analyzed using the mathematical expression $\ln W t=\ln a+b \ln$ $s L$, where: $\mathrm{Wt}=$ total weight, $\mathrm{a}=$ intercept, $\mathrm{b}=$ slope and $s L=$ standard length (Santos, 1978, adapted by Braga, 1986). The regression model was tested with F-test performed on R (R Development Core Team, 2011). A $t$-test was run on Bioestat (Ayres et al., 2007) to verify if the slope is different from three, i.e. to search for allometric relationships: positive if the slope is higher than three, and negative if it is lower than three (Benedito-Cecílio and Agostinho, 1997).

Sex and stage of gonad maturation of the captured fish, were determined by macroscopic inspection (Vazzoler, 1996) and, subsequently, sex ratio was calculated. Immediately after capture, a $10 \%$ buffered formalin solution was injected through the body wall into the stomach cavity
(Montenegro et al., 2006). The significance of differences between the proportions of both sexes throughout the different seasons was evaluated using chi-square $\left(\chi^{2}\right)$ tests in Statistica software, version 6.0 (Statsoft, 1998).

\subsection{Reproductive and feeding structures}

Maturation stages of the gonads were determined following Vazzoler (1996) and, subsequently, the species' reproductive activity was determined. To test the level of significance between maturation stages throughout the seasons, chi-square tests $\left(\chi^{2}\right)$ were conducted using $\mathrm{R}$ software ( $\mathrm{R}$ Development Core Team, 2011).

To determine if the sex ratio of $S$. notonota individuals was different than expected, considering an even male to female proportion, a chi-square $\left(\chi^{2}\right)$ test was conducted. Further, chi-square was also employed to test seasonal changes in sex ratio (data pooled together as 2005 dry season, 2006 rainy season and 2006 dry season). These tests were conducted on Statistica software 6.0 (Statsoft, 1998).

Feeding activity was determined based on stomach repletion degree, and reproductive activity based on degree of gonad maturation. The degree of stomach fullness was classified according to Hahn et al. (1997), whereas the degree of gonad maturation followed Vazzoler (1996).

The relationship between feeding and reproductive activities were evaluated with Spearman's correlation (significance level of 0.05) by correlating individuals with concomitant feeding and reproductive activities.

Feeding habitats (diet and alimentary regime) were investigated with the analysis of stomach of the same individuals whose reproduction had been previously determined. Stomach contents were removed in laboratory and preserved in a $75^{\circ} \mathrm{GL}$ ethanol solution, until further macroscopic and microscopic analyses. Food items were identified to the lowest possible taxonomic level, based in specialized references (e.g. Edmonson, 1959; Germain, 1981; Menezes and Dias, 2001) and with the aid of taxonomy experts in various areas.

Diet was determined using the frequency of occurrence method, which estimates the number of occurrences of an item relative to the total number of analyzed stomachs (Zavala-Camim; 1996). Additionally, the points method (Hynes, 1950; Fugi et al., 1996; Resende et al., 2000; Peret, 2004) was employed. In the latter method, the point of each food item was multiplied by the respective 
stomach weight (Hynes, 1950). The Alimentary Index (IAi) for each item consumed was calculated to identify the most important food items in the diet of $S$. notonota, following Kawakami and Vazzoler (1980) (Equation 1):

$$
\mathrm{IAi}_{\mathrm{i}}=\left(\mathrm{Fo}_{\mathrm{i}} \cdot \mathrm{FP}_{\mathrm{i}} / \sum_{\mathrm{i}=1}^{\mathrm{n}} \mathrm{Fo}_{\mathrm{i}} \cdot \mathrm{Fp}_{\mathrm{i}}\right) \cdot 100
$$

where: $\mathrm{IAi}_{\mathrm{i}}=$ relative alimentary importance index for the $\mathrm{i}^{\text {th }}$ species, $\mathrm{Fo}_{\mathrm{i}}=$ frequency of occurrence of the $\mathrm{i}^{\text {th }}$ species, $\mathrm{Fp}_{\mathrm{i}}=$ point frequency of the $\mathrm{i}^{\text {th }}$ species.

\section{Results}

\subsection{Population structure}

A total of 120 individuals were captured, as seen in Table 1. S. notonota individuals varied between 2.2 to $10.7 \mathrm{~cm}$ in total length with a mode of 7.8 . Through whole study period, the highest standard length values observed were $10.7 \mathrm{~cm}$ for females (mean: $8.8 \mathrm{~cm}$ ) and $9.7 \mathrm{~cm}$ for males (mean: 8.1), with no significant differences in the size between sexes $(t=1.97 ; d f=58 ; p=0.053)$. Also, no significant differences were found between sexes when analyzing isolated dry/2005 $\left(\mathrm{t}_{9.9,2(0.05)}=1.72\right.$, $\mathrm{p}=0.117)$ and rainy/2006 $\left(\mathrm{t}_{12.93,2(0.05)}=1.13\right.$,

Table 1. Abundance of Steindachnerina notonota individuals collected throughout the study period according the fish gear.

\begin{tabular}{lcccc}
\hline \multicolumn{1}{c}{ Fishing gear } & Dry/05 & Rainy/06 & Dry/06 & Total \\
\hline Cast net $(15 \mathrm{~mm})$ & - & - & 2 & 2 \\
Gill net $(15 \mathrm{~mm})$ & 77 & 26 & 1 & 104 \\
Gill net $(20 \mathrm{~mm})$ & 11 & - & - & 11 \\
Gill net $(35 \mathrm{~mm})$ & - & - & 2 & 2 \\
Seine net $(0.2 \mathrm{~mm})$ & - & 1 & - & 1 \\
\hline
\end{tabular}

$\mathrm{p}=0.278$ ) seasons. There were no enough specimens to test the dry/2006 season (Figure 3).

Gonad maturation analyses indicated that the majority of individuals feel within the categories 'in maturation' (2) and 'mature' (3) (Figure 4). This pattern was observed during a hydrological cycle, suggesting a multivoltine reproduction for S. notonota. Although temporal differences were observed in the frequency of maturation stages $\left(\chi_{6,2(0.05)}^{2}=16.294 ; \mathrm{p}=0.012\right)$, these differences were mostly observed within stage 1 , and may explained by chance alone, as observed from the standardized residual results (Table 2).

Weight of $S$. notonota individuals varied from 0.31 to $43.1 \mathrm{~g}$, with an amplitude of $42.8 \mathrm{~g}$. The regression model to the weight-length relationship is $\ln W \mathrm{t}=-1.35+2.83 . \ln s L\left(\mathrm{~F}_{1 \text { and } 118(0,05)}=948,7\right.$; $\mathrm{p}<0.001)$. The slope shows a negative allometric growth $\left(\mathrm{b}=2.829: \mathrm{t}_{118,1(0,05)}=-1,86, \mathrm{p}=0,032\right.$; Figure 5). S. notonota had a significantly higher proportion of females throughout the study $\left(\chi^{2}=14.25, \mathrm{df}=1, \mathrm{p}<0.01\right)$, with a male-female ratio of 1.0:3.0 (Figure 6).

\subsection{Reproductive activities and feeding structure}

Feeding activity of $S$. notonota was higher than $80 \%$ throughout the study period while the reproductive activity was low (less than 30\%) (Figure 7). Furthermore, the relationship between feeding and reproductive activities was not significant when analyzed by the Spearman correlation coefficient ( $r s=0.05 ; \mathrm{p}=0.92)$.

$S$. notonota individuals used for stomach content analysis ranged from 2.2 to $10.7 \mathrm{~cm}$ total length. A total of 88 items were identified, $82.95 \%$ of which were encountered during the dry season of $2005,68.17 \%$ during the rainy season of 2006 and $26.14 \%$ during the dry season of 2006 (Table 3).

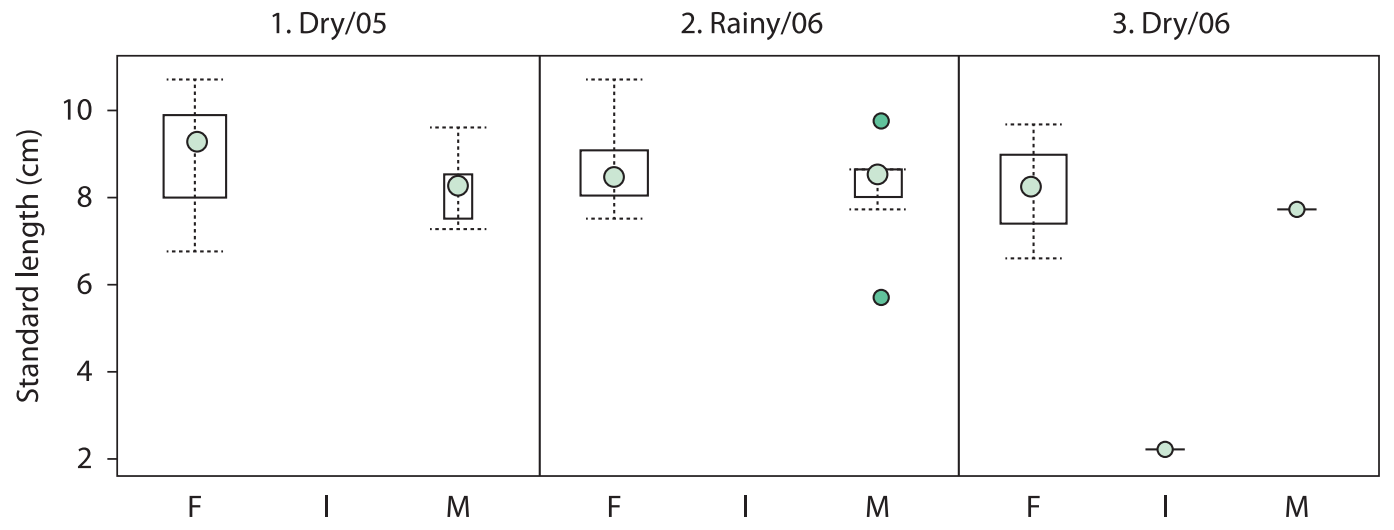

Figure 3. Standard length $(\mathrm{cm})$ of males (M), females (F) e immature (I) of Steindachnerina notonota in each period studied. The box width is proportional to sample size. 
Table 2. Standardized residuals for the $\chi^{2}$ test over the level of gonad maturation of $S$. notonota collected throughout the study period $\left(\chi_{6,2(0.05)}^{2}=16.294 ; \mathrm{p}=0.012\right)$.

\begin{tabular}{lrrr}
\hline Maturation stage & Dry/05 & Rainy/06 & \multicolumn{1}{c}{ Dry/06 } \\
\hline 1 (Immature) & -1.0946297 & -0.7844430 & $3.3744135^{*}$ \\
2 (in maturation) & -0.8865215 & 1.0664866 & -0.2737759 \\
3 (mature) & 0.5281997 & 0.2112049 & -1.3326700 \\
4 (exhausted) & 1.2130453 & -1.8156328 & 1.0041750 \\
\hline
\end{tabular}

*differences from expected are significant $(\mathrm{p}<0.05)$ if standardized residuals are lower than -1.96 or higher than 1.96.

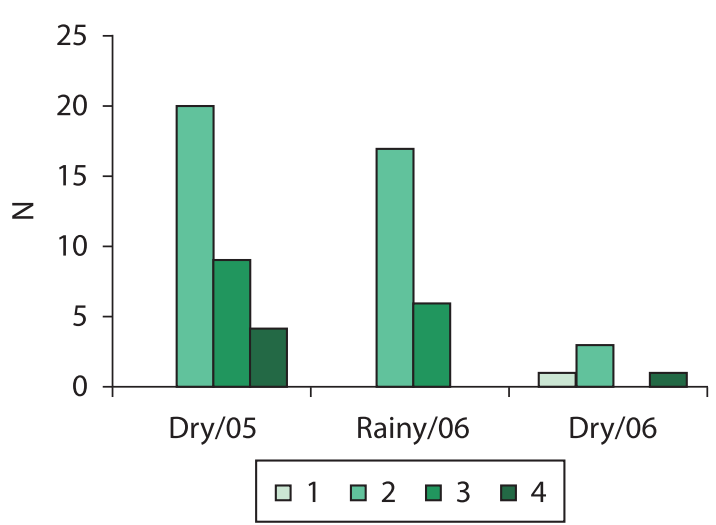

Figure 4. Gonad maturation of Steindachnerina notonota in Taperoá II dam, Taperoá city, Paraíba State, Brazil, in each study period. 1) immature; 2) in maturation; 3) mature; and 4) exhausted.

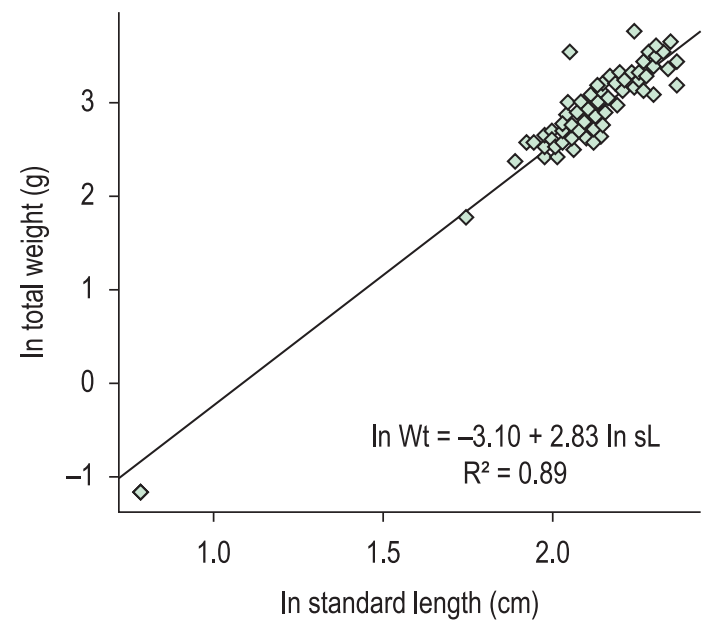

Figure 5. Length/weight relationship of Steindachnerina notonota in Taperoá II dam, Taperoá city, Paraíba State, Brazil, along the study period.

Debris was the most important feeding item, followed by plant remains. Furthermore, the highest amplitude of diet was recorded during the 2005 dry season, where items such as sediment, algae (e.g. Amphora sp., Melosira italica, Oocystis sp., etc) and Chironomidae larvae and pupae were exclusively recorded during this season.

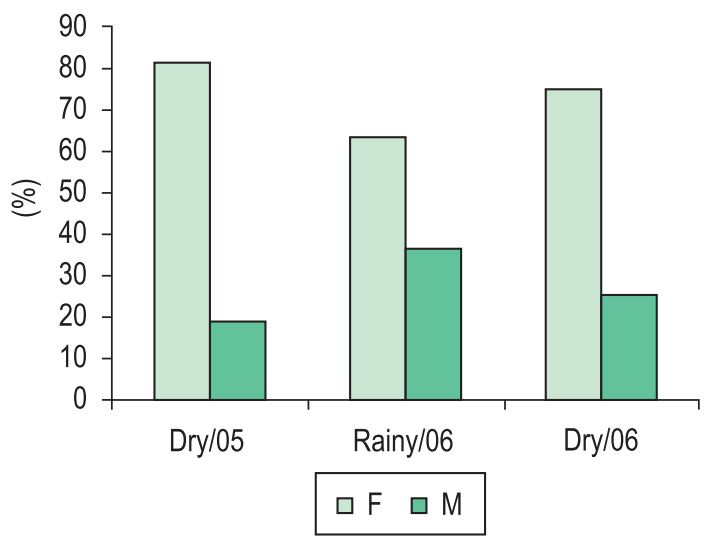

Figure 6. Sexual proportion of Steindachnerina notonota in Taperoá II dam, Taperoá city, Paraíba State, Brazil, in each study period.

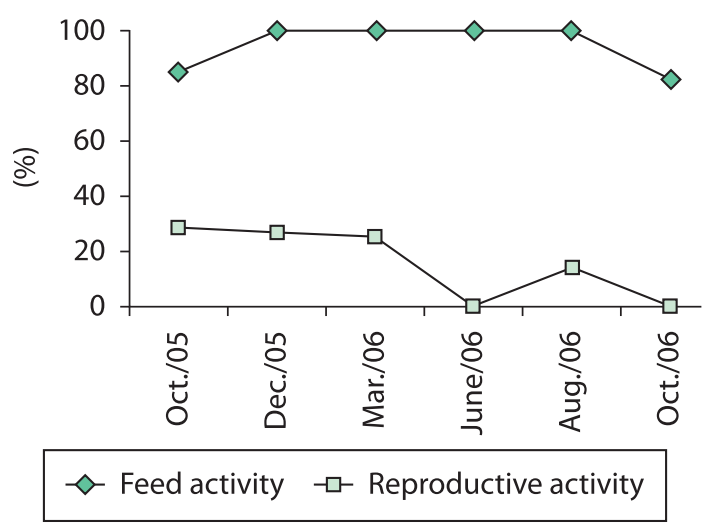

Figure 7. Feeding activity X reproductive activity of Steindachnerina notonota in Taperoá II dam, Taperoá city, Paraíba State, Brazil, in each study period.

\section{Discussion}

The observed reduction in the number of Steindachnerina notonota indivuals throughout the study period was, certainly, related to the overflow of the reservoir during the 2006 rainy season, which dislodged individuals downstream. 
Table 3. Frequency of occurrence ( $\mathrm{Fo}$ ), points frequency (Fp) and index of food importance (AIi - Alimentary Importance Index) of food items of Steindachnerina notonota registered in Taperoá II Dam, Taperoá - PB, along the study period.

\begin{tabular}{|c|c|c|c|c|c|c|c|c|c|}
\hline \multirow{3}{*}{$\begin{array}{c}\text { Season } \\
\text { Number of stomachs } \\
\text { Items } \\
\end{array}$} & \multicolumn{3}{|c|}{ Dry/05 } & \multicolumn{3}{|c|}{ Rainy/06 } & \multicolumn{3}{|c|}{ Dry/06 } \\
\hline & \multicolumn{3}{|c|}{88} & \multicolumn{3}{|c|}{27} & \multicolumn{3}{|c|}{5} \\
\hline & Fo & $\mathrm{Fp}$ & $\mathrm{IAi}$ & Fo & $\mathrm{Fp}$ & $\mathrm{IAi}$ & Fo & $\mathrm{Fp}$ & $\mathrm{IAi}$ \\
\hline Debris & 84.2 & 14.1 & 19.8 & 95.0 & 14.7 & 23.1 & 100.0 & 22.5 & 33.5 \\
\hline Fish scales & 5.3 & 0.8 & 0.1 & 15.0 & 1.2 & 0.3 & - & - & - \\
\hline Organic matter & 68.4 & 5.1 & 5.8 & 75.0 & 6.7 & 8.3 & 60.0 & 11.9 & 10.6 \\
\hline Egg & 89.5 & 3.7 & 5.5 & 80.0 & 5.8 & 7.8 & 80.0 & 9.7 & 11.5 \\
\hline Vegetable remains & 100.0 & 10.0 & 16.7 & 95.0 & 13.6 & 21.5 & 80.0 & 10.6 & 12.6 \\
\hline Sediment & 57.9 & 4.4 & 4.3 & - & - & - & - & - & - \\
\hline Seeds & 47.4 & 3.0 & 2.4 & 35.0 & 3.2 & 1.8 & - & - & - \\
\hline \multicolumn{10}{|l|}{ PHYTOPLANKTON } \\
\hline \multicolumn{10}{|l|}{ Bacylariophyceae } \\
\hline Amphora sp. & 15.8 & 0.5 & 0.1 & - & - & - & - & - & - \\
\hline Cocconeis sp. & - & - & - & - & - & - & 20.0 & 0.6 & 0.2 \\
\hline Cyclotella meneghiniana & 68.4 & 2.5 & 2.9 & 40.0 & 2.0 & 1.4 & 40.0 & 2.5 & 1.5 \\
\hline Cymbella sp. & 10.5 & 0.5 & 0.1 & - & - & - & 60.0 & 5.0 & 4.5 \\
\hline Ephitemia sp. & 5.3 & 0.2 & 0.0 & 5.0 & 0.3 & 0.0 & 40.0 & 3.1 & 1.8 \\
\hline Diploneis sp. & - & - & - & 5.0 & 0.5 & 0.0 & - & - & - \\
\hline Eunotia pectinalis & 5.3 & 0.2 & 0.0 & 5.0 & 0.3 & 0.0 & 20.0 & 2.2 & 0.7 \\
\hline Fragillaria sp. & 10.5 & 0.5 & 0.1 & - & - & - & - & - & - \\
\hline Gyrosigma sp. & 68.4 & 2.5 & 2.9 & 20.0 & 1.2 & 0.4 & - & - & - \\
\hline Mastogloia smithii & 31.6 & 1.7 & 0.9 & 5.0 & 0.5 & 0.0 & 40.0 & 1.5 & 0.9 \\
\hline Melosira granulata & 89.5 & 4.5 & 6.7 & 95.0 & 3.9 & 6.1 & 100.0 & 5.6 & 8.4 \\
\hline Melosira italica & 26.3 & 0.9 & 0.4 & - & - & - & - & - & - \\
\hline Navicula sp1. & 52.6 & 2.4 & 2.1 & 15.0 & 0.7 & 0.2 & 40.0 & 1.5 & 0.9 \\
\hline Navicula sp2. & 26.3 & 1.0 & 0.4 & 10.0 & 0.8 & 0.1 & - & - & - \\
\hline Neidium sp. & - & - & - & 5.0 & 0.5 & 0.0 & - & - & - \\
\hline Nitzschia sp. & 15.8 & 0.5 & 0.1 & 20.0 & 0.8 & 0.3 & 20.0 & 0.6 & 0.2 \\
\hline Pinnularia sp. & 31.6 & 1.4 & 0.7 & 25.0 & 1.1 & 0.5 & 40.0 & 2.2 & 1.3 \\
\hline Surirella sp. & 26.3 & 1.1 & 0.5 & 10.0 & 0.7 & 0.1 & 40.0 & 1.5 & 0.9 \\
\hline Synedra sp1 & 47.4 & 1.5 & 1.2 & 10.0 & 0.6 & 0.1 & - & - & - \\
\hline Synedra sp2. & 5.3 & 1.0 & 0.1 & 10.0 & 0.5 & 0.1 & - & - & - \\
\hline \multicolumn{10}{|l|}{ Chlorophyceae } \\
\hline Filamentous algaes & 31.6 & 1.5 & 0.8 & 20.0 & 1.3 & 0.4 & 40.0 & 2.8 & 1.7 \\
\hline Ankistrodemus convolutus & 15.8 & 0.7 & 0.2 & 5.0 & 0.1 & 0.0 & - & - & - \\
\hline Ankistrodesmus falcatus & 21.1 & 0.9 & 0.3 & 5.0 & 0.6 & 0.1 & 20.0 & 0.6 & 0.2 \\
\hline Ankistrodesmus spiralis & 5.3 & 0.1 & 0.0 & - & - & - & - & - & - \\
\hline Chlorela vulgaris & 100.0 & 4.2 & 6.9 & 100.0 & 4.3 & 7.1 & 60.0 & 1.5 & 0.6 \\
\hline Chrocooccus sp. & 15.8 & 0.4 & 0.1 & 10.0 & 0.6 & 0.1 & - & - & - \\
\hline Chrocooccus turgidus & 10.5 & 0.6 & 0.1 & - & - & - & - & - & - \\
\hline Closterium sp. & 10.5 & 0.4 & 0.1 & 10.0 & 0.3 & 0.0 & - & - & - \\
\hline Eudorina elegans & - & - & - & 0.5 & 0.2 & 0.0 & - & - & - \\
\hline Kirchneriella contorta & 10.5 & 0.3 & 0.1 & - & - & - & - & - & - \\
\hline Kirchneriella sp. & - & - & - & 5.0 & 0.4 & 0.0 & - & - & - \\
\hline Scenedesmus bijugatus & - & - & - & 5.0 & 0.5 & 0.0 & - & - & - \\
\hline Scenedesmus quadricauda & 5.3 & 0.1 & 0.0 & 5.0 & 0.5 & 0.0 & - & - & - \\
\hline Schroederia setigera & - & - & - & 5.0 & 0.2 & 0.0 & - & - & - \\
\hline Selenastrum sp. & - & - & - & 5.0 & 0.2 & 0.0 & - & - & - \\
\hline $\begin{array}{l}\text { Spyrogira sp. } \\
\text { Cianophyceae }\end{array}$ & - & - & - & 5.0 & 0.5 & 0.0 & - & - & - \\
\hline Anabaena sp. & 84.2 & 3.0 & 4.3 & 35.0 & 1.7 & 1.0 & - & - & - \\
\hline Calotrix sp. & 5.3 & 0.2 & 0.0 & - & - & - & - & - & - \\
\hline
\end{tabular}


Table 3. Continued...

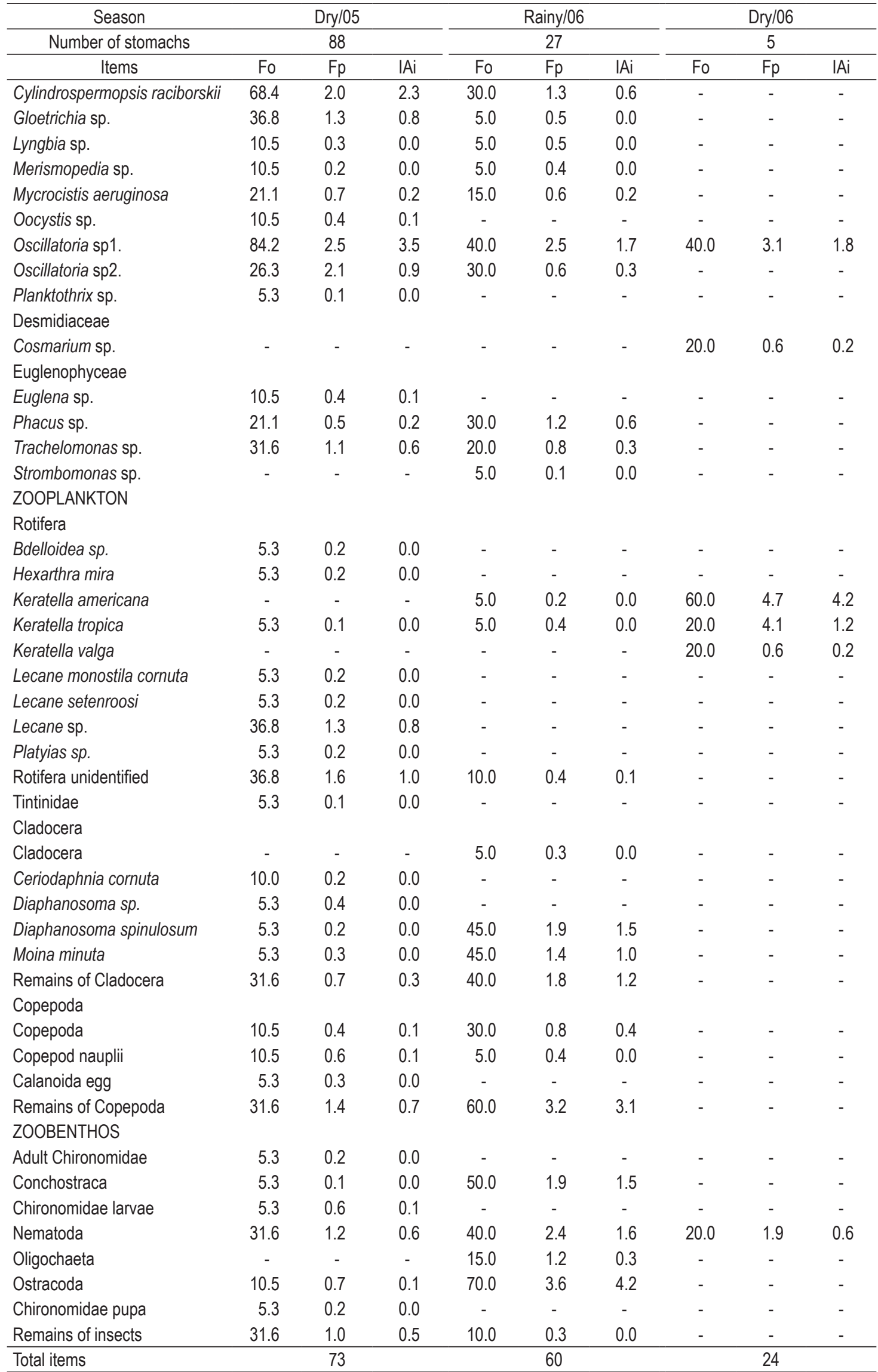


This is supported by the fact that sampling effort was temporally standardized and by intensive local fishermen activities at the study site.

Sizes very similar to those reported here were recorded by Gurgel et al. (2005), in Ceará Mirim River, Rio Grande do Norte State, that found individuals of $S$. notonota slightly larger (3.2 to 11.0) than those the present study. Further, most individuals fell within $8-9 \mathrm{~cm}$ size in the present study.

Large individuals (i.e. adults) ranging between 8 and $10.7 \mathrm{~cm}$ predominated during the 2005 dry season and during the 2006 rainy season, whereas a single small individual $(2.2 \mathrm{~cm})$ was recorded during the 2006 dry season. However, reproductively active individuals were observed throughout the whole study period, suggesting that this species has a broad recruitment period. Also, this is indicative that $S$. notonota does not rely strongly on hydrological regimes.

Length-weight relationship investigations contribute to the knowledge of species morphology and provide a basis for comparisons with other populations. The angular coefficient (b) is an allometric value which determines the growth type of a species (condition factor) and, according to Benedito-Cecílio and Agostinho (1997), it is generally constant, gently fluctuating close to the 3.0 value, where there is a corresponding increase in the weight of different fish body parts, illustrating an isometric type of growth. On the other hand, values higher and lower than 3.0 suggest, respectively, positive and negative allometric types of growth. In these cases, the weight of different body parts increase independently.

In the present study, $S$. nototona had a negative allometric growth type. According to Orsi et al. (2002), a higher increase in length relative to weight is observed during the development of a given individual with this type of growth. Also, according to Santos et al. (2004), populations with large fishes usually show low allometric coefficients, given that they stop allocating energy for body growth. Values below 3.0 indicate that individuals become more 'elongated' throughout their development.

Length-weight relationships can be influenced by several factors such as food availability, population density and environmental factors which in interaction may affect the values of these variables. They may also suffer the influence of body biomass, gonad maturity, fish growth, degree of parasitism, gender, age and fishing (Lambert et al. 1994; Ribeiro and Castro, 2000).
The type of growth observed for Steindachnerina notonota is common for many species. For example, S. insculpta, a related species from the same genus investigated by Holzbach et al. (2005), also showed a negative allometric type of growth, for both females and males $(b=2.79$ and $b=1.97$, respectively).

The higher proportion of females in the present study is also an adaptation to food supply, given that, according to Nikolsky (1969), females prevail when food availability is high. Feeding activity, in this case, would be influencing metabolism through hormonal activity, resulting in changes in production of individuals of a given sex. This was also observed in Taperoá Dam II, mostly due to the presence of macrophytes and, therefore, an increase in the availability of shelter and food.

The relationship between feeding and reproductive activities was not significant throughout the study period, given that the individuals maintained a high feeding activity, above $80 \%$, and a low reproductive activity, lower than $29 \%$. Another fact to consider is that, according to Moreira-Hara et al. (2005), the reproductive cycles of organic detritus consumers (e.g. S. notonota) is only subtly influenced by the effects of seasonality, given that this food item is abundantly available along the year. However, the availability of detritus was not evaluated in the Taperoá dam.

As widely registered before (Montenegro et al., 2006), this species has a very broad diet, but debris and plant remains (Table 2) were the most important food items during all periods, indicating a detritivorous diet.

In the dry season of 2005 a wider diet was observed and some food items, such as sediment, some algae (Amphora sp., Aulacoseira granulata, Oocystis sp., among others) and Chironomidae larvae and pupae, were unique for this period. This was probably related to a higher concentration of food items during the dry period. However, this was not observed in the drought of 2006, probably due to the unusual large volume of water in the dam and thus, the resulting dilution of food items in the environment.

Teixeira and Gurgel (2005) studied feeding dynamics of Steindachnerina notonota in the Cross Creek dam (RN) and detected a diet based mostly on debris, like the present study. The same observation was made by Montenegro et al. (2006), who studied the influence of methodology on diet analysis of this species in Taperoá II dam, and Gurgel et al. (2005), which also found a diet 
composed mostly by sediments $(\mathrm{IAi}=0.53)$ and algae $(\mathrm{IAi}=0.35)$.

The results of the present study, corroborate the available literature about the family Curimatidae, providing information on another species that is also detritivorous (e.g. Pereira and Resende, 1997; Giora and Fialho, 2003; Melo et al., 2004).

We highlight the lack of studies on the population dynamics of $S$. notonota, which preclude meticulous comparisons that make conservation and management studies impracticable. Also, from an ecological point of view, this species is prey for other species, such as Hoplias malabaricus (Bloch, 1794)(Montenegro, 2007), and, despite the fact that it is not of high commercial importance, it is commonly consumed by local people.

\section{Acknowledgements}

We are grateful to Long Term Ecological Research, PELD/Caatinga - CNPq (Conselho Nacional de Desenvolvimento Científico e Tecnológico) for the support and CAPES (Coordination of Improvement of Higher Education) for a master degree grant to Ana Karla Araujo Montenegro and CNPq.

\section{References}

AYRES, M., AYRES JUNIOR, M., AYRES, DL. and DOS SANTOS, AS. 2007. Manual BioEstat 5.0. Belém: Imprensa Oficial do Estado do Pará. 323 p.

BENEDITO-CECÍlIO, E. and AGOSTINHO, AA. 1997. Estrutura das populações de peixes do reservatório de Segredo. In AGOSTINHO, AA. and GOMES, LC., eds. Reservatório de Segredo: bases ecológicas para o manejo. Maringá: EDUEM. 387 p.

BRAGA, FMS. 1986. Estudo entre fator de condição e relação peso-comprimento para alguns peixes marinhos. Brazilian Journal of Biology, vol. 46, no. 2, p. 339-346.

BRITISKI, HA. 1972. Peixes de água doce do Estado de São Paulo. Sistemática. In Comissão Interestadual da Bacia do Paraná-Uruguay. Poluição e Piscicultura, notas sobre ictiologia, poluição e piscicultura. São Paulo: Faculdade de Saúde Pública da USP, Instituto de Pesca. p. 79-108.

CARDOSO, MML., SOUZA, JERT. and SANTANA, ACD. 2004. Estrutura da comunidade de peixes dos açudes Namorados e Afogados, semi-árido paraibano. In Anais do VI Simpósio Patrimônio Ameaçado, 2004. São José dos Campos: Instituto Tecnológico de Aeronáutica.

CHAVES, MF., TORELLI, J., TARGINO, CH. and CRISPIM, MC. 2009. Dinâmica reprodutiva e estrutura populacional de Hoplias aff. malabaricus
(Bloch, 1794) (Characiformes, Erythrinidae) em açude da bacia do rio Taperoá, Paraíba. Biotemas, vol. 22 , no. 2 , p. $85-89$.

COWX, IG., YOUNG, WO., and HELLAWELL, JM. 1984. The influence of drought on the fish and invertebrate populations of an upland stream in Wales. Freshwater Biology, vol. 14, p. 165-77.

EDMONSON, WT. 1959. Freshwater Biology. New York: John Wiley \& Sons, INC. 1248 p.

FERNANDO, CH. 1991. Impacts of fish introductions in Tropical Asia and America. Canadian Journal of Fisheries and Aquatic Sciences, vol. 48, sup. 1, p. 24-33.

FUGI, R., HAHN, NS. and AGOSTINHO, AA. 1996. Feeding styles of five species of bottom-feeding fishes of the high Paraná River. Environmental Biology of Fishes, vol. 46, p. 297-307. http://dx.doi. org/10.1007/BF00005006

GERMAIN, H. 1981. Flore dês diatomées dês eaux douces et saumâtres. Paris: Société Nouvelle dês éditions Boubée. 444 p.

GIORA, J. and FIALHO, CB. 2003. Biologia alimentar de Steindachnerina brevipinna (Characiformes, Curimatidae) do Rio Ibicuí-Mirim, Rio Grande do Sul, Brasil. Iheringia, Série Zoologia, vol. 93, no. 3, p. 277-281.

GURGEL, HCB., SILVA, NB., LUCAS, FD. and SOUZA, LLG. 2005. Alimentaçáo da comunidade de peixes do rio Ceará Mirim, em Umari, Taipu, Estado do Rio Grande do Norte, Brasil. Acta Scientiarum. Animal Sciences, vol. 27, no. 2, p. 229-233.

HAHN, NS., FUGI, R., ALMEIDA, VLL., RUSSO, MR. and LOUREIRO, VE. 1997. Dieta e atividade alimentar de peixes do reservatório de Segredo. In AGOSTINHO, AA. and GOMES, LC., eds. Reservatório de Segredo: bases ecológicas para o manejo. Maringá: EDUEM. 387 p.

HOLZBACH, AJ., BAUMGARTNER, G., BERGMANN, F., REZENDE-NETO, LB; BAUMGARTNER, D., SANCHES, PV. and GUBIANI, EA. 2005. Caracterização populacional de Steindachnerina insculpta (Fernández-Yépez, 1948) (Characiformes, Curimatidae) no rio Piquiri. Acta Scientiarum. Biological Sciences, vol. 27, no. 4, p. 347-353.

HYNES, HBN. 1950. The food of freshwater sticklebacks (Gasterostreus aculeatus and Pygosteus pungitius), with a review of methods used in studies of the food of fishes. Journal Animal Ecology, vol. 19, no. 1, p. 36-58. http://dx.doi.org/10.2307/1570

KAWAKAMI, E. and VAZZOLER, R. 1980. Método gráfico e estimativa de índice alimentar aplicado no 
estudo de alimentação de peixes. Boletim do Instituto Oceanográfico, vol. 29, p. 205-207.

KÖPPEN, W. 1900. Classificação do clima de Köppen. Available from: <http://tiosam. com/?q=Classifica\%C3\%A7\%C3\%A3o_do_clima_ de_K\%C3\%B6ppen>.

LAMBERT, Y., DUTIL, JD., and MUNRO, J. 1994. Effects of intermediate and low salinity conditions on growth rate and food conversion of Atlantic cod (Gadus morhua). Canadian Journal of Fisheries and Aquatic Sciences, vol. 51, p. 1569-1576

LATINI, AO. 2001. O efeito da introdução de peixes exóticos nas populaçóes nativas de lagoas do Parque Estadual do Ri Doce, $M G$. Belo Horizonte: Universidade Federal de Viçosa. [Dissertação de Mestrado em Ecologia (Conservação e Manejo da Vida Silvestre)].

LIZAMA, MAP. and AGOSTINHO, AM. 2003. Crescimento, recrutamento e motilidade do pequi Moenkhausia intermedia (Osteichthyes, Characidae) na planície de inundação do alto rio Paraná, Brasil. Acta Scientiarum. Biological Sciences, vol. 25, no. 2, p. 329-333.

MELO, CE., MACHADO, FA. and PINTO-SILVA, V. 2004. Feeding habitats of fish from a stream in the savanna of Central Brazil, Araguaia Basin. Neotropical Ichthyology, vol. 2, no. 1, p. 37-44. http://dx.doi. org/10.1590/S1679-62252004000100006

MENEZES, M. and DIAS, ICA. 2001. Biodiversidade de algas de ambientes continentais do estado Rio de Janeiro. Rio de Janeiro: Museu Nacional do Rio de Janeiro. 256 p.

MONTENEGRO, AKA., CRISPIM, MC., TORELLI, J. and MARINHO, RSA. 2006. The influence of the methodology in the results of food diet analysis of Steindachnerina notonota (Miranda-Ribeiro, 1937), in Taperoá II dam, PB - Caatinga. Revista de Biologia e Ciências da Terra, vol. 1, p. 180-191.

MONTENEGRO, AKA. 2007. Bioecologia da ictiofauna do açude Taperoá II, semi-árido paraibano, Brasil. João Pessoa: Universidade Federal da Paraíba. 143 p. [Dissertação de Mestrado em Zoologia].

MONTENEGRO, AKA., TORELLI, J., MARINHO, RSA., CRISPIM, MC. and HERNANDEZ, MIM. 2010. Aspects of the feeding and population structure of Leporinus pian Fowler, 1941 (Actinopterygii, Characiformes, Anostomidae) of Taperoá II Dam, semi arid region of Paraíba, Brazil. Biotemas, vol. 23, no. 2, p. 101-110.

MOREIRA-HARA, SS., ZUANON, J. and AMADIO, S. 2005. Relação entre o ciclo hidrológico e as atividades alimentar e reprodutiva de quatro espécies de peixes no Catalão, uma área de várzea na Amazônia Central. Available from: <http://www.seb-ecologia.org.br/ viiceb/resumos/961a.pdf>.
NIKOLSKY, GV. 1969. The theory of fish population dynamics. Edinburg: Oliver \& Boyd Ltd. 320 p.

ORSI, ML., SHIBATTA, OA. and SILVA-SOUZA, AT. 2002. Caracterização biológica de populações de peixes do rio Tibagi, localidade de Sertanópolis. In MEDRI, ME., ed. A Bacia do rio Tibagi. Londrina: Universidade Estadual de Londrina. 595 p.

PEREIRA, RAC. and RESENDE, EK. 1997. Peixes detritivoros da planície inundável do rio Miranda, Pantanal, Mato Grosso do Sul. Corumbá: EMBRAPACPAP. (EMBRAPA-CPAP, Boletim de Pesquisa, no. 12).

PERET, AM. 2004. Dinâmica da alimentação de peixes piscivoros da represa de Três Marias (MG). São Carlos: Universidade Federal de São Carlos. 60 p. [Dissertação de Mestrado em Ecologia e Recursos Naturais].

PIMENTA-FILHO, EC., SARMENTO, JLR. and RIBEIRO, MN. 2004. Efeitos genéticos e ambientais que afetam a produção de leite e duração da lactação de cabras mestiças no estado da Paraíba. Revista Brasileira de Zootecnia, vol. 33, no. 6, p. 1426-1431.

R Development Core Team. 2011. R: A language and environment for statistical computing. Vienna: $\mathrm{R}$ Foundation for Statistical Computing. Available from: <http://www.r-project.org/>.

RESENDE, EK., PEREIRA, RAC., ALMEIDA, VLL. and SILVA, AG. 2000. Peixes onivoros da planicie inundável do rio Miranda, Pantanal, Mato Grosso do Sul, Brasil. Corumbá: Embrapa Pantanal. 44 p. Boletim de Pesquisa. Available from: <http://www. cpap.embrapa.br/publicacoes/online/BP16.pdf>.

RIBEIRO, D. and CASTRO, ACL. 2003. Contribuição ao estudo da dinâmica populacional do Tralhoto Anablebs anableps (Teleostei, Cyprinidontiformes), no município de Bacuri, estado do Maranhão. Boletim do Laboratório de Hidrobiologia, vol. 16, p. 21-27.

ROSA, RS., MENEZES, NA., BRITSKI, EA., COSTA, WJEM. and GROTH, F. 2005. Diversidade, padrōes de distribuição e conservação dos peixes da Caatinga. In LEAL, IR., TABARELLI, M. and SILVA, JMC., eds. Ecologia e Conservação da Caatinga. 2th ed. Recife: Ed. Universitária UFPE. 822 p.

SANTOS, EP. 1978. Dinâmica de Populaçôes Aplicada à Pesca e Piscicultura. São Paulo: HUCITEC, Ed. da Universidade de São Paulo. 129 p.

SANTOS, ALB., PESSANHA, ALM., COSTA, MR. and ARAÚJO, FG. 2004. Relação pesocomprimento de Orthopristis ruber (Curvier) (Teleostei, Haemulidae) na Baia de Sepetiba, Rio de Janeiro, Brasil. Revista Brasileira de Zoologia, vol. 21, no. 2, p. 185-187. http://dx.doi.org/10.1590/S010181752004000200004 
SOARES, MGM., ALMEIDA, RG. and JUNK, WJ. 1986. The trophic status of the fish fauna in Lago Camaleão, a macrophyte dominated floodplain lake in the middle Amazon. Amazoniana, vol. 9. p. 511-526.

STATSOFT. 1998. Statistica for Windows. Tulsa: Statsoft Inc. [Computer Program].

TEIXEIRA, JLA. and GURGEL, HCB. 2005. Ocorrência e distribuição temporal da ictiofauna do Açude Riacho da Cruz, no Rio Grande do Norte. Revista Ceres, vol. 1, no. 2, p. 1-8.

VARI, RP. 1991. Systematics of the neotropical Characiform genus Steindachnerina Fowler (Pisces: Ostariophysi).
Washington: Smithsonian Contributions to Zoology. 118 p.

VAZZOLER, AEAM. 1996. Biologia da reprodução de peixes Teleósteos: Teoria e Prática. Maringá: EDUEM. 169 p.

VICENTINI, RN. and ARAÚJO, FG. 2003. Sex ratio and size structure of Microspogonias furnieri (Desmarest, 1823) (Perciformes, Sciaenidae) in Sepetiba bay, Rio de Janeiro, Brazil. Brazilian Journal of Biology, vol. 63, no. 4, p. 559-566. http://dx.doi. org/10.1590/S1519-69842003000400003

ZAVALA-CAMIN, LA. 1996. Introdução aos estudos sobre alimentação natural em peixes. Maringá: EDUEM. 129 p. 